\title{
Forbyd selvmords-hjemmesiderne
}

\author{
Ved Kim Engelbrechtsen
}

\section{Danmark har et forslag om at gøre det strafbart at lave hjemmesider med opskrifter på selumord vaeret til første behandling i Folketinget. I Landsforeningen for efterladte efter selumord har vi anbefalet et internationalt samarbejde på linje med kampen mod børneporno, så vi for alvor kan komme uvaesenet til livs.}

En søgning på G oogle efter ordene suicide og methods giver flere hundre tusen links til forskellige Internet sider. En del af disse er "uskyldige", f.eks. forskningsartikler. $M$ en en lang række links fører direkte ind på sider, hvor selvmord fremstilles som en naturlig løsning, ja nærmest en anbefalingsværdig udvej. Sproget er kammeratligt, og der følger i mange tilfæl de nøjagtige anvisninger og tegninger med. D rik så og så meget, brug den slags reb, så mange piller skal du tage.

Disse Internet sider har allerede ført til flere selvmord i Danmark og andre lande. Jeg har selv haft problemet uhyggeligt tæt inde på livet. For tre år siden stod en sådan hjemmeside nemlig fremme på min søns computerskærm, da han val gte at tage sit eget liv en mørk nattetime - kun 16 år gammel. Siden viste, hvordan man hænger sig selv fra et dørhåndtag - og han havde desværre ful gt anvisningen til punkt og prikke.

Det var selvfølgelig ikke hjemmesiden, der var hans motiv til at tage sit eget liv, men den var hans "redskab" på linje med en kniv, et gevær eller en overdosis piller. Ja, faktisk var siden værre, fordi den påvirkede hans skrøbelige sind og lokkede ham i døden.

I januar 2003, altså godt et halvt år efter min søns død, blev sagen rejst i det danske Folketing af Elsebeth $\mathrm{G}$ erner $\mathrm{N}$ iel sen, som er folketingsmedlem for $D$ et radikale Venstre og på daværende tidspunkt sad i bestyrelsen for $L$ andsforeningen for efterladte efter selvmord. $H$ un redegjorde for problemstillingen og spurgte, hvad Justitsministeren havde tænkt sig at gøre ved den.

Svaret var, at man ikke uden videre ville lave om på straffeloven, men at man gerne ville se på erfaringerne fra udlandet, ikke mindst Frankrig, hvor der er lavet en tilføjelse i lovgivningen, som siger, at det er strafbart at propagandere for og give opskrift på sel vmord i massemedierne. I den danske straffelov er det "kun" strafbart at medvirke til selvmord, og ordlyden ville forholdsvis enkelt kunne udvides til også at gælde det at give anvisninger på selvmord.

I november 2003 bad jeg om foretræde for Folketingets R etsudvalg sammen med overlæge M erete N ordentoft, Bispebjerg $\mathrm{H}$ ospital, og O le K yed, formand for U nicef Danmark. Vi fremlagde her vore synspunkter til støtte for et eventuelt lovindgreb og bad udval get om at fremme sagen. I marts 2004 fremsatte D et radikale Venstre og Socialistisk Folkepartiet et beslutningsforlag i Folketinget om forbud mod selvmordshjemmesider. Forslaget gav anledning til debat - også i medierne. $\mathrm{N}$ ogle mente, at det burde vedtages umiddelbart, mens andre mente, at det var svært at lovgive om den slags, da de eksisterende hjemmesider med selvmordsopskrifter kommer fra udlandet - ikke mindst USA , og da Internettets kaotiske struktur gør det svært at dæmme op over for den slags. Endelig var der ytringsfriheden at tage hensyn til.

Forslagsstillerne argumenterede for, at et forbud - selv om det måske i første

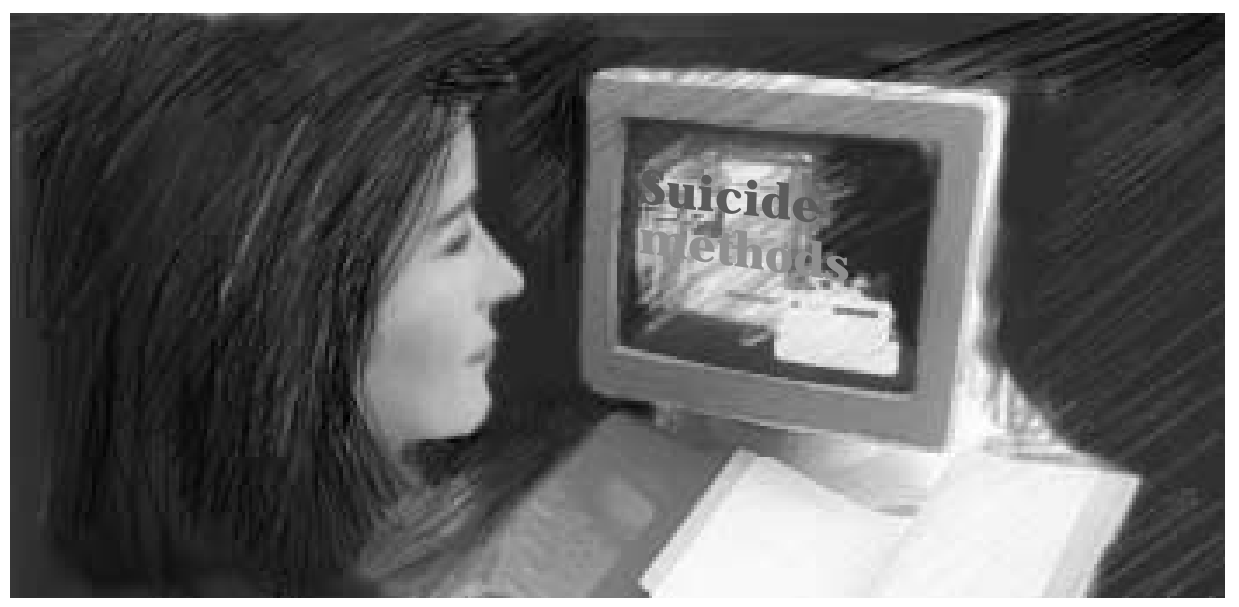

omgang kun vil få en symbolsk værdi på længere sigt kan bane vejen for et internationalt samarbejde, som vi kender det fra kampen mod børneporno. Et dansk forbud her og nu vil betyde, at vi har fejet for egen dør og vist vejen for andre lande omkring os. Vi ville kunne tage Frankrig "i hånden" og gå i spidsen for et internationalt samarbejde.

Selv om der faktisk sá ud til at være et flertal for at vedtage beslutningsforslaget uden om regeringen, blev der i sidste øjeblik indgået et kompromis, som gik ud på at sende forslaget til vurdering i Straffelovrådet med henblik på at undersøge eventuelle uheldige konsekvenser af en ændring af straffeloven. Straffel ovrådet skal "for så vidt muligt" komme med et svar senest den 1. oktober 2005.

Både det store danske tel eselskab T DC og Rigspolitichefen har udtalt, at hvis der kommer et forbud, vil det også kunne håndhæves.

I august 2004 havde Elsebeth G erner $\mathrm{N}$ iel sen og jeg begge et indlæg på et europæisk symposium i København, hvor selvmordsforskere fra hele Europa var tilstede. $\mathrm{H}$ er redegjorde vi for de danske initiativer og anbefal ede deltagerne at tage hjem og påvirke deres respektive landes regeringer til at gøre noget ved problemet med selvmordshjemmesiderne. Denne opfordring vil jeg gerne gentage her.

Lad os sammen prøve at gøre noget ved sagen. $H$ vad nytter det, at vi forbyder farlige film for børn under 15 àr, hvis de kan gå på nettet og blive opfordret til og instrueret $i$ at tage deres eget liv?

Vel bliver det ikke nemt at komme uvæsenet helt til livs, og vel tager ting tid, som poeten Piet $\mathrm{H}$ ein sagde - ikke mindst når det drejer sig om politik, kunne man tilføje, men vi må da gøre noget. Vi kan da ikke bare lade som om, problemet ikke eksisterer.

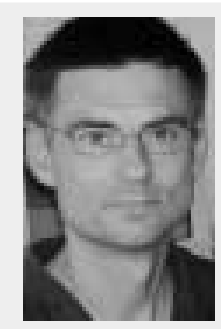

Kim Engelbrechtsen er dansk journalist og medlem af Landsforeningen for efterladte efter selvmord. 